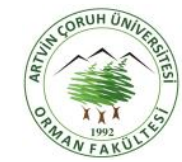

\title{
Morphological variations based on geometric morphometrics between male and female pronota of Oxythyrea cinctella (Schaum, 1841) (Coleoptera: Scarabaeidae, Cetoniinae)
}

\author{
Oxythyrea cinctella'nın (Schaum, 1841) (Coleoptera: Scarabaeidae, Cetoniinae) erkek ve dişi pronotumu arasındaki \\ geometrik morfometriye dayalı morfolojik varyasyonlar
}

\author{
Yavuz KOÇAK ${ }^{1}\left(\mathbb{D}\right.$, Aslı DOĞAN SARIKAYA ${ }^{2}$, Özkan SARIKAYA ${ }^{3}$ (i), Ülfet ŞAHIN ${ }^{4}$ (i) \\ ${ }^{1}$ Ankara Hacı Bayram Veli University, Faculty of Polatlı Art Science, Department of Biology, Ankara, TURKEY \\ ${ }^{2}$ Kırşehir Ahi Evran University, Faculty of Art and Science, Department of Anthropology, Kırşehir, TURKEY, \\ ${ }^{3}$ Kırşehir Ahi Evran University, Faculty of Health Science, Department of Child Development, Kırşehir, TURKEY \\ ${ }^{4}$ Ankara Hacı Bayram Veli University, Institute of Graduate Studies, Department of Biology, Ankara, TURKEY
}

Eser Bilgisi / Article Info

Araştırma makalesi / Research article

DOI: 10.17474/artvinofd.985036

Sorumlu yazar / Corresponding author

Yavuz KOÇAK

e-mail: yavuz.kocak@hbv.edu.tr

Geliş tarihi / Received

20.08.2021

Düzeltme tarihi / Received in revised form

07.11.2021

Kabul Tarihi / Accepted

08.11.2021

Elektronik erişim / Online available

19.11.2021

Keywords:

Oxythyrea cinctella

Scarab beetle

Pronotum

Landmark-based morphometry

Sexual dimorphism

Anahtar kelimeler:

Oxythyrea cinctella

Scarab kınkanatlısı

Pronotum

Landmark temelli morfometri

Eşeysel dimorfizm

\begin{abstract}
In this study, pronotum size and shape were used as an exemplar characteristic to evaluate the utility of pronotal morphology on the sexual dimorphism determination of the scarab beetle Oxythyrea cinctella (Schaum, 1841). Using geometric morphometrics, the sexual size and shape dimorphism of pronotum of 85 specimens ( 45 females, 40 males) collected from Ankara Province (Turkey) were analyzed. Results of geometric morphometrics revealed that there is statistically significant sexual size and shape dimorphism in pronotum. Further, the mean centroid sizes of the females was significantly larger than that of the males. Finally, multivariate regression results indicated that size has negligible influence on the differentiation in pronotum shape between sexes. We hope the results here presented would be helpful for the further understanding of the sexual dimorphism in the beetle genus Oxythyrea.
\end{abstract}

\section{Özet}

Bu çalışmada, pronotal morfolojinin Oxythyrea cinctella (Schaum, 1841)'nın eşeysel dimorfizminin tayini için pronotum büyüklüğü ve şekli örnek bir özellik olarak kullanılmıştır. Ankara ilinden (Türkiye) toplanan 85 örneğin (45 dişi, 40 erkek) pronotumu geometrik morfometri ile eşeysel boyut ve şekil dimorfizmi analiz edildi. Geometrik morfometrinin sonuçları, pronotumda istatistiksel olarak anlamlı eşeysel boyut ve şekil dimorfizmi olduğunu ortaya koydu. Ayrıca, dişilerin ortalama centroid boyutu erkeklerden önemli ölçüde daha büyüktü. Son olarak, çok değişkenli regresyon sonuçları, boyutun eşeyler arasındaki pronotum şeklindeki farklılaşma üzerinde inmal edilebilir bir etkiye sahip olduğunu göstermiştir. Burada sunulan sonuçların Oxythyrea cinsi böceklerde eşeysel dimorfizmin daha iyi anlaşılması için yararlı olacağını umuyoruz.

\section{INTRODUCTION}

Oxythyrea cinctella (Schaum, 1841) belongs to the genus Oxythyrea Mulsant, 1842 in the subfamily Cetoniinae Leach, 1815 within the family Scarabaeidae Latreille, 1802. Like $O$. cinctella, phytophagous beetles of Scarabaeidae are plant pests of great economic importance in agriculture, forestry, and horticulture (Jackson and Klein 2006). O. cinctella is an economically significant pest that has the potential to cause regular damage to agriculture and native ecosystems. This species was included in the lists of harmful fauna as examples reported in apricot orchards (Öztürk et al. 2004, Apak 2021), cherry orchards (Tezcan and Pehlivan 2001), oil-bearing rose production fields (Demirözer and Karaca 2011, Demirözer et al. 2011), temperate region fruit trees (Özbek 2008), ornamental plants and saplings (Kaygin et al. 2008) in Turkey and the neighbouring countries (Modarres Awal 2006, Augul 2016, Bunalski et al. 2016, Yusifov et al. 2016).

Geometric morphometrics has increasingly become more available tool to reveal previously undocumented morphological patterns in entomological research (Tatsuta et al. 2018). Internal or external rigid structures of the many insects such as pronotum, elytra, mandible, genitalia, horn, hind tibia, hind femur, metendosternite have been widely used in the geometric morphometric- 
based assessment of morphological variations (Pretorius et al. 2000, Garnier et al. 2005, Rodrigues et al. 2005, Polihronakis 2006, Romiti et al. 2017, Da Silva et al. 2018, Juache et al. 2018, Kerman et al. 2018, Zhang et al. 2019). Of these, the pronotum, the hardened dorsal plate of the prothorax, is of great importance not only to bear important muscles and support the locomotion of prothoracic legs (Garnier et al. 2005, Zhang et al. 2019) but also provide some constant characters, present some differences between the species and offer useful characters in classification (Wood 1963, Ali 1978). Besides, previous studies have indicated that the morphological characteristics of the pronotum are used to help determine sexual dimorphism (Assing 2006, Pomfret and Knell 2006, Petrov et al. 2007, Reaney and Knell 2015, Li et al. 2020). Moreover, much of our understanding of the morphological variations between male and female pronota are derived from geometric morphometric researches (Vergara et al. 2014, Eldred et al. 2016, Carillo and Dela Cruz 2018, Vesović et al. 2019, Regueira et al. 2020).

Although geometric morphometric studies have currently focused on the determination of intraspecific shape variations (Polihronakis 2006), morphological differentiation patterns in polyphenic sister species (Pizzo et al. 2006), differentiating new species (Li et al. 2016), the characterization of biogeographically isolated populations (Barros et al. 2020) of various scarab beetles, none attempt has been made on Oxythyrea beetles so far. Here we thus aimed to assess the degree of sexual dimorphism between the sexes of $O$. cinctella through pronotum morphology by using landmark-based analyses for the first time.

\section{MATERIALS AND METHODS}

In this study, specimens of $O$. cinctella were collected from Ankara Province (Ayaş, Kazan, Kızılcahamam) (Figure 1), Turkey on March-April 2020 and preserved in $70 \%$ ethanol. All individuals were dissected using fine forceps and insect pins under a stereomicroscope to observe genitalia for sexing them.

The pronotum of the specimens were photographed in a dorsal view using a Leica camera attached to a Leica binocular microscope. TPSdig2 (Rohlf 2017) program was used to digitize and save 13 landmarks for the dorsal view of the pronotum (Figure 2). The landmark coordinates of 85 specimens ( 45 females, 40 males) were used for the pronotum size and shape analysis.
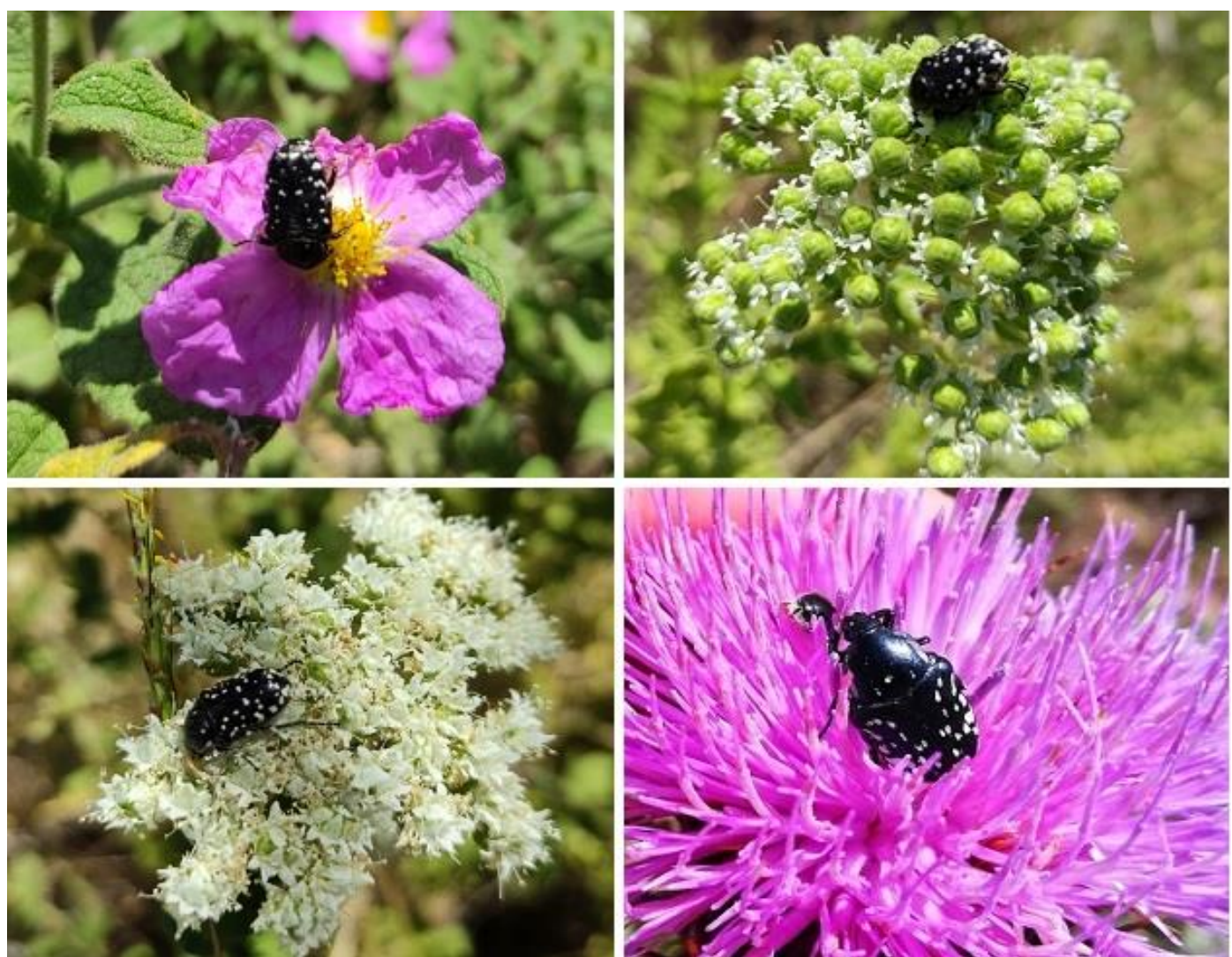

Figure 1. Adult specimens of Oxythyrea cinctella on various plants (C Y. Koçak) 


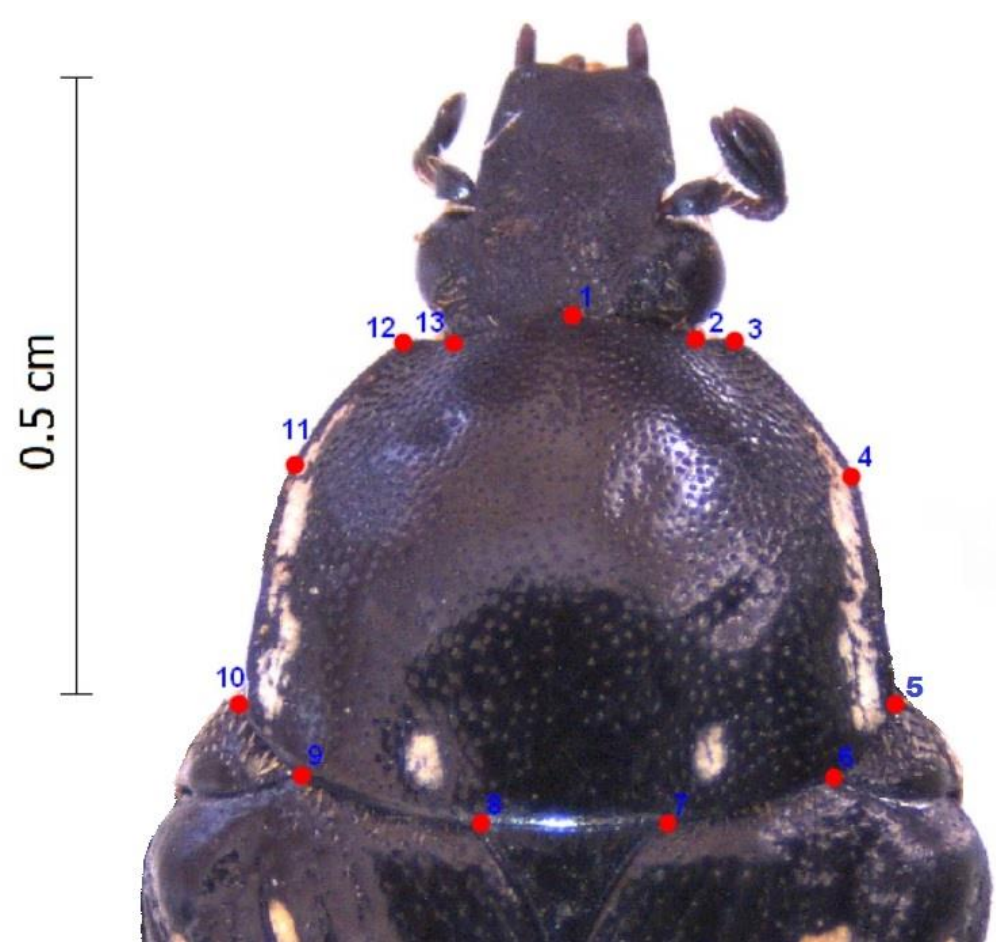

Figure 2. Dorsal view of Oxythyrea cinctella showing positions of 13 landmarks used to define the shape of pronotum

Landmark-based morphometric methods were used asses to pronotum shape and size between sexes and MophoJ v1.07a (Klingenberg 2011) was used for all analyses of landmarks configurations. To compare pronotum size between sexes, the centroid size (CS) (square root of the sum of the square distances between each landmark and the centroid) (Bookstein 1986) was computed. The independent samples t-test was performed using the IBM SPSS25 to test pronotum size variation between sexes. A generalized procrustes analysis (GPA) has been developed to superimposition of landmark configurations and to eliminate the effects of translation, rotation, and scale (Rohlf 1999). Principal component analysis (PCA) was used to reduce the dimensionality of the landmark dataset and so into finding new variables that are linear functions of those in the landmark dataset, that successively maximize variance, and that are uncorrelated with each other. Then multivariate regression analysis was performed to determine the effect of size on shape. Finally, discriminant function analysis (DFA) with cross validation was performed to determine the degree of morphological distinction between sexes.

\section{RESULTS AND DISCUSSION}

\section{Size Variation}

The independent samples t-test showed that the CS means of males is significantly different from that of females (Table 1). Figure 3 shows a box-plot of CS between sexes. Further, the females appear to be larger than the males for CS of pronotum.

Table 1. Independent t-test results

\begin{tabular}{|c|c|c|c|c|c|c|c|c|c|c|}
\hline & & & & & & $\begin{array}{l}\text { Levene's Test for } \\
\text { Variances }\end{array}$ & Equality of & $\begin{array}{l}\text { t-test fo } \\
\text { Means }\end{array}$ & or & ality of \\
\hline & Sex & $\mathrm{N}$ & Mean & Std. Deviation & Std.Error Mean & $\mathrm{F}$ & Sig. & $\mathrm{t}$ & $d f$ & Sig. \\
\hline \multirow[t]{2}{*}{ CS } & Female & 45 & 1092.86 & 90.25 & 13.45 & 1.354 & 0.248 & 2.594 & 83 & 0.011 \\
\hline & Male & 40 & 1045.28 & 77.29 & 12.22 & & & & & \\
\hline
\end{tabular}




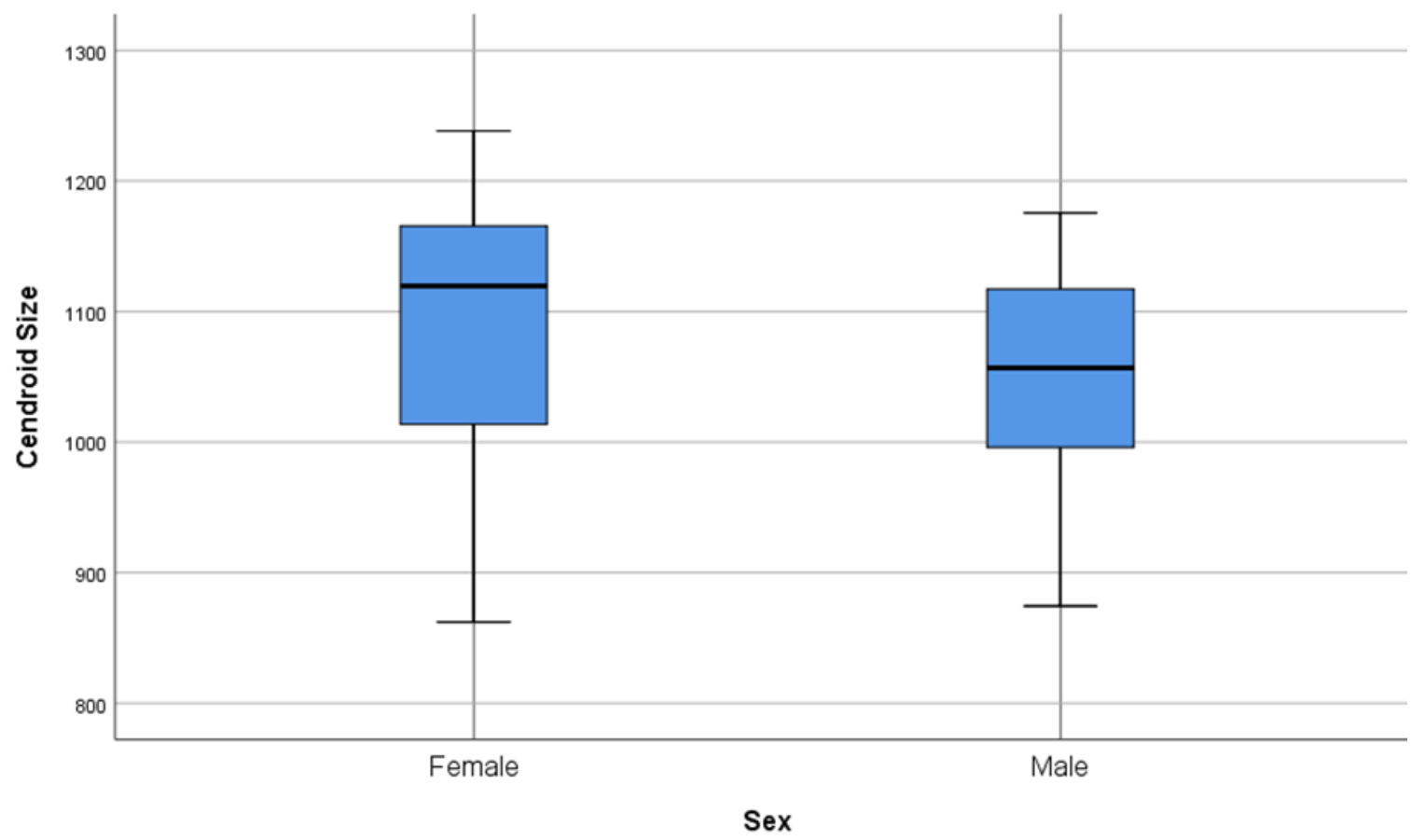

Figure 3. Box-plot of centroid size for pronotum for males and females of Oxythyrea cinctella

\section{Shape Variation}

Principal component analysis (PCA) showed that $41.3 \%$ of the total variation of pronotum shape was explained by the first two principal components (PC1 explains $26.7 \%$ and PC2, 14.6\%) (Table 2). Twenty-two main components were required to explain the total shape variation of pronotum.

Table 2. Principal component analysis results

\begin{tabular}{|c|c|c|c|}
\hline & Eigenvalues & Variance\% & Cumulative\% \\
\hline 1 & 0.00049861 & 26.669 & 26.669 \\
\hline 2 & 0.00027354 & 14.631 & 41.299 \\
\hline 3 & 0.00021696 & 11.604 & 52.903 \\
\hline 4 & 0.00015034 & 8.041 & 60.944 \\
\hline 5 & 0.00011493 & 6.147 & 67.091 \\
\hline 6 & 0.00010848 & 5.802 & 72.894 \\
\hline 7 & 0.00008214 & 4.393 & 77.287 \\
\hline 8 & 0.00006132 & 3.280 & 80.567 \\
\hline 9 & 0.00005999 & 3.209 & 83.775 \\
\hline 10 & 0.00005784 & 3.094 & 86.869 \\
\hline 11 & 0.00005080 & 2.717 & 89.586 \\
\hline 12 & 0.00003809 & 2.037 & 91.623 \\
\hline 13 & 0.00002949 & 1.577 & 93.200 \\
\hline 14 & 0.00002504 & 1.340 & 94.540 \\
\hline 15 & 0.00002427 & 1.298 & 95.838 \\
\hline 16 & 0.00001916 & 1.025 & 96.863 \\
\hline 17 & 0.00001607 & 0.860 & 97.723 \\
\hline 18 & 0.00001302 & 0.696 & 98.419 \\
\hline 19 & 0.00001018 & 0,545 & 98.963 \\
\hline 20 & 0.00000759 & 0.406 & 99.369 \\
\hline 21 & 0.00000603 & 0.323 & 99.692 \\
\hline 22 & 0.00000576 & 0.308 & 100.000 \\
\hline
\end{tabular}


Although multivariate regression of shape on centroid size was statistically significant that explained only 4.64 percent of the total variation in the shape of pronotum (4.64\%, $p=0.0003)$. On the other words, pronotum shape differences have not related to the size of the pronotum.
Discriminant function analysis (DFA) was performed to determine the degree of morphological separation between the sexes. Cross-validated correct classification percentage was $82.36 \%$ between sexes $(86.7 \%$ for females and $77.5 \%$ for males) (Figure 4). DFA showed that there is a statistically significant difference between means of procrustes distance of sexes $(p<0.0001)$.

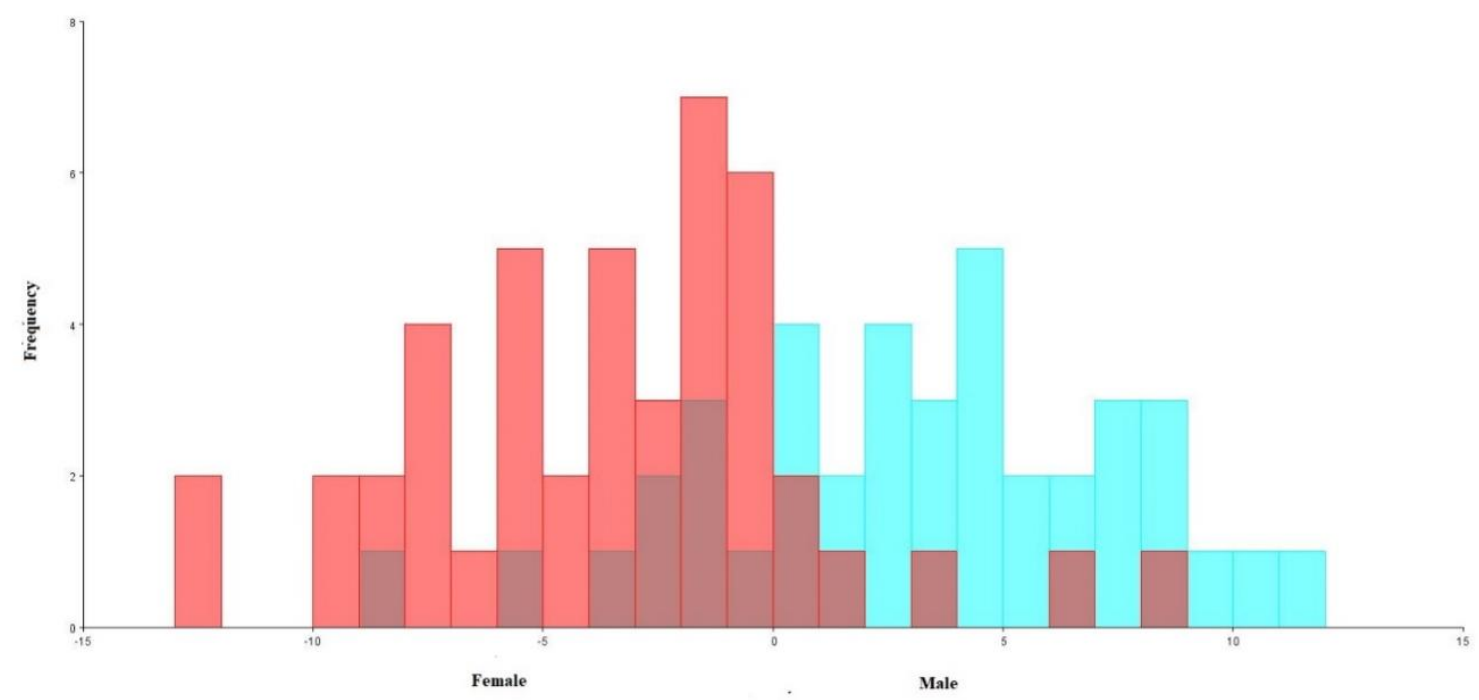

Figure 4. Cross-validation scores of shape variables of pronotum

Also, the results of DFA show that all the landmarks with the greatest variation indicating that females have a wider and shorter pronotum than males. This is also related to elongation and sharpened from both anterior and posterior parts of the pronotum shape in males (Figure 5). According to shape variation in landmarks 3, 4, $5,6,8,9$, and 10 females' pronota were wider and shorter than those of the males.

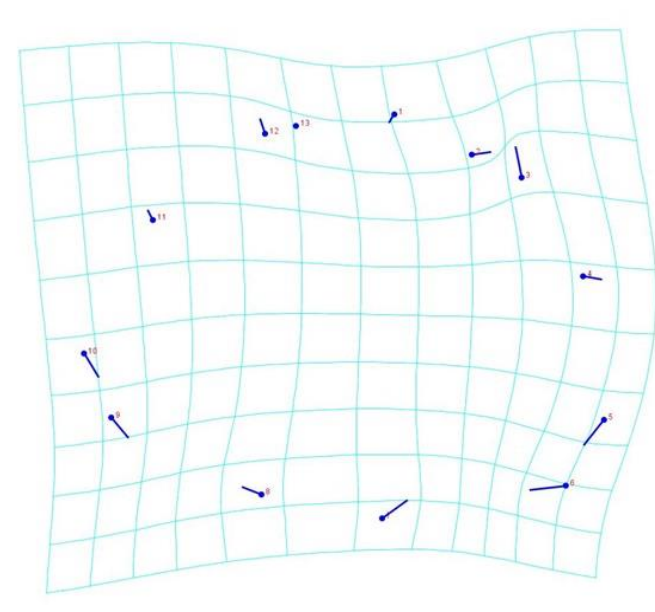

Female

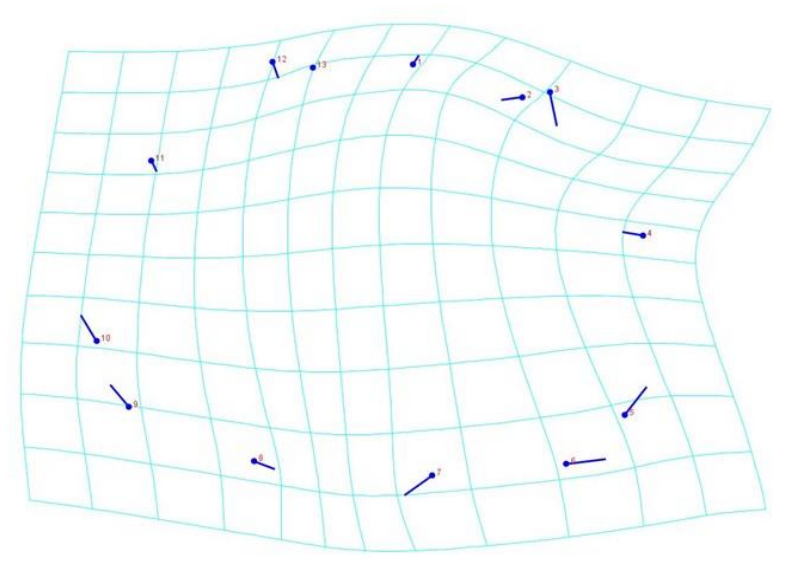

Male

Figure 5. The dots show the average of the female and male specimens (The length of the lines shows the amount of change between the sexes and in which direction this change is directed)

The main goal of the present study is to apply geometric morphometrics for the first time to pronotum of the scarab beetle species, Oxythyrea cinctella in order to assess the presence of sexual dimorphism in size and shape. Significant sexually dimorphic differences have been found in the present study confirming earlier pronotal studies in beetles (Eldred et al. 2016, Li et al. 2016, Ober and Connolly 2015, Pizzo et al. 2006). As a 
conclusion, it can be stated that sexual dimorphism in the pronotum size and shape of $O$. cinctella can be used to discriminate between sexes. Moreover, it shows that the pronotum could be the preferred structure for morphometric analyses since it is particularly suitable for landmark based geometric morphometrics. Finally, additional studies are needed to explore reasons (ecological niche, feeding and reproductive behaviors etc.) behind sexual differences in the pronotum size and shape. Further studies including different populations of this species plus different body parts (head, elytra etc.) should also be performed to understand the process in which sexual dimorphism is affected.

\section{ACKNOWLEDGMENT}

This work has been funded by the Scientific Research Projects Unit of Ankara Hacı Bayram Veli University, Project № 01/2021-03.

\section{REFERENCES}

Ali HA (1978) Faunistic study of the Cicindelidae (Coleoptera) of Iraq and southwest Asia. Coleopt Bull 32(1): 1-20.

Apak FK (2021) Pests species determined in apricot orchards in Malatya province, Turkey. Fresenius Environ Bull 30(2): 14761480.

Assing V (2006) New species and records of Staphylinidae from Turkey IV, with six new synonymies. Koleopterol Rundsch 76: 223-276.

Augul RS (2016) Insect pollinators in different regions of Iraq. J Entomol Zool Stud 4(2): 391-402.

Barros RP, Astua D, Grossi PC, lannuzzi L, Maia ACD (2020) Landmarkbased geometric morphometrics as a tool for the characterization of biogeographically isolated populations of the pollinator scarab beetle Erioscelis emarginata (Coleoptera: Melolonthidae). Zool Anz 288: 97-102.

Bookstein FL (1986) Size and shape spaces for landmark data in two dimensions. Stat Sci 1(2): 181-222.

Bunalski M, Samin N, Ghahari H (2016) A contribution to the faunistic study of Scarabaeoidea (Coleoptera) from Mazandaran province, northern Iran. Wiad Entomol 35(1): 31-40.

Carillo DM, Dela Cruz IN (2018) Disparity in the pronotal shapes between sexes in the two populations of Brontispa longissima (Gestro, 1885) from Caraga region, Philippines using landmarkbased geometric morphometrics. Comput Ecol Softw 8(3): 62-74.

Da Silva ACS, Nunes LA, De Lima Batista W, Lhano MG (2018) Morphometric variation among males of Orphulella punctata (De Geer, 1773) (Acrididae: Gomphocerinae) from different biomes in Brazil. J Orthoptera Res 27(2): 163-171.

Demirözer O, Karaca i (2011) Phytophagous arthropod species associated with oil bearing rose, Rosa damascena Miller, in Isparta province with distributional remarks. Süleyman Demirel University Journal of Science 6(1): 9-25.

Demirözer O, Karaca I, Karsavuran Y (2011) Population fluctuations of some important pests and natural enemies found in oil-bearing rose (Rosa damascena Miller) production areas in Isparta province (Turkey). Turk Entomol Derg 35(4): 539-558.
Eldred T, Meloro C, Scholtz C, Murphy D, Fincken K, Hayward M (2016) Does size matter for horny beetles? A geometric morphometric analysis of interspecific and intersexual size and shape variation in Colophon haughtoni Barnard, 1929, and C. kawaii Mizukami, 1997 (Coleoptera: Lucanidae). Org Divers Evol 16(4): 821-833.

Garnier S, Magniez-Jannin F, Rasplus JY, Alibert P (2005) When morphometry meets genetics: inferring the phylogeography of Carabus solieri using Fourier analyses of pronotum and male genitalia. J Evol Biol 18(2): 269-280.

Jackson TA, Klein MG (2006) Scarabs as pests: a continuing problem. Coleopt Bull 60(mo5): 102-119.

Juache A, Ordenes R, Benítez HA (2018) Quantifying the shape variation of the elytra in Patagonian populations of the ground beetle Ceroglossus chilensis (Coleoptera: Carabidae). Zool Anz 274: 123-126.

Kaygin AT, Sönmezyildiz H, Ülgentürk S, Özdemir I (2008) Insect species damage on ornamental plants and saplings of Bartin province and its vicinity in the Western Black Sea region of Turkey. Int J Mol Sci 9(4): 526-541.

Kerman K, Roggero A, Rolando A, Palestrini C (2018) Evidence for male horn dimorphism and related pronotal shape variation in Copris lunaris (Linnaeus, 1758) (Coleoptera: Scarabaeidae, Coprini). Insects 9(108): 1-13.

Klingenberg CP (2011) MorphoJ: an integrated software package for geometric morphometrics. Mol Ecol Resour 11(2): 353-357.

Li H, Wu C, Ohl M, Liu X (2020) A new sexually dimorphic mantidfly species of Allomantispa Liu et al., 2015 from China (Neuroptera: Mantispidae). J Asia Pac Entomol 23(4): 988-1002.

Li S, Ricchiardi E, Bai M, Yang X (2016) A taxonomy review of Oreoderus Burmeister, 1842 from China with a geometric morphometric evaluation (Coleoptera, Scarabaeidae, Valgini). ZooKeys 552: 6789.

Modarres Awal M (2006) Preliminary studies on Scarabaeoidea (Coleoptera) fauna of Razavi Khorasan province of Iran. Turk Entomol Derg 30(3): 163-172.

Ober KA, Connolly CT (2015) Geometric morphometric and phylogenetic analyses of Arizona Sky Island populations of Scaphinotus petersi Roeschke (Coleoptera: Carabidae). Zool J Linnean Soc 175(1): 107-118.

Özbek H (2008) Türkiye'de ılıman iklim meyve türlerini ziyaret eden böcek türleri. Uludağ Arıcılık Dergisi 8(3): 94-105.

Öztürk N, Ulusoy MR, Erkılıç L, Bayhan ÖS (2004) Malatya ili kayısı bahçelerinde saptanan zararlılar ile avcı türler. Bitki Koruma Bülteni 44(1-4): 1-13.

Petrov AV, Mandelshtam MY, Beaver RA (2007) Urocorthylus gen. n.: a remarkable monotypical scolytine genus from northern Vietnam. Koleopterol Rundsch 77: 249-254.

Pizzo A, Mercurio D, Palestrini C, Roggero A, Rolando A (2006) Male differentiation patterns in two polyphenic sister species of the genus Onthophagus Latreille, 1802 (Coleoptera: Scarabaeidae): a geometric morphometric approach. J Zool Syst Evol Res 44(1): 5462.

Polihronakis M (2006) Morphometric analysis of intraspecific shape variation in male and female genitalia of Phyllophaga hirticula (Coleoptera: Scarabaeidae: Melolonthinae). Ann Entomol Soc Am 99(1): 144-150.

Pomfret JC, Knell RJ (2006) Sexual selection and horn allometry in the dung beetle Euoniticellus intermedius. Anim Behav 71(3): 567-576.

Pretorius R, Philips K, Scholtz C (2000) Geometric morphometrics, the metendosternite and its use in phylogenetics of the Scarabaeinae (Coleoptera). Elytron 14: 125-148. 
Reaney LT, Knell RJ (2015) Building a beetle: how larval environment leads to adult performance in a horned beetle. Plos One 10(8): e0134399, 1-14.

Regueira JC, Damasceno EM, lannuzzi L (2020) Shape variation of Cydianerus latruncularius (Coleoptera, Curculionidae) across biomes and sexes. Zool Anz 289: 96-107.

Rodrigues D, Sanfelice D, Monteiro LR, Moreira GR (2005) Ontogenetic trajectories and hind tibia geometric morphometrics of Holymenia clavigera (Herbst) and Anisoscelis foliacea marginella (Dallas) (Hemiptera: Coreidae). Neotrop Entomol 34(5): 769-776.

Rohlf FJ (1999) Shape statistics: Procrustes superimpositions and tangent spaces. J Classif 16: 197-223.

Rohlf FJ (2017) tpsDig, 2.17. (Web page: https://life.bio.sunysb.edu/morph) (Date accessed:15 May 2021).

Romiti F, Redolfi De Zan L, Piras P, Carpaneto GM (2017) Shape variation of mandible and head in Lucanus cervus (Coleoptera: Lucanidae): a comparison of morphometric approaches. Biol J Linn Soc Lond 120(4): 836-851.

Tatsuta H, Takahashi KH, Sakamaki Y (2018) Geometric morphometrics in entomology: basics and applications. Entomol Sci 21(2): 164184.
Tezcan S, Pehlivan E (2001) Evaluation of the Lucanoidea and Scarabaeoidea (Coleoptera) fauna of ecological cherry orchards in İzmir and Manisa provinces of Turkey. Ege Üniversitesi Ziraat Fakültesi Dergisi 38(2-3): 31-37.

Vergara O, Benitez HA, Pincheira M, Jerez V (2014) Sexual dimorphism in body shape of Chiasognathus grantii (Coleoptera: Lucanidae). Rev Colomb Entomol 40(1): 104-110.

Vesović N, Ivanović A, Ćurčić S (2019) Sexual size and shape dimorphism in two ground beetle taxa, Carabus (Procrustes) coriaceus cerisyi and C. (Morphocarabus) kollari praecellens (Coleoptera: Carabidae) - A geometric morphometric approach. Arthropod Struct Dev 49: 1-9.

Wood SL (1963) A revision of the bark beetle genus Dendroctonus Erichson (Coleoptera: Scolytidae). Great Basin Nat 23(1-2): 1-117.

Yusifov EF, Ahmadov BA, Narimanova VS (2016) Diversity study of scarab beetles belonging to the subfamily Cetoniinae spread in the natural region of the greater Caucasus of Azerbaijan. J Entomol Zool Stud 4(5): 1118-1122.

Zhang M, Ruan Y, Wan X, Tong Y, Yang X, Bai M (2019) Geometric morphometric analysis of the pronotum and elytron in stag beetles: insight into its diversity and evolution. ZooKeys 833: 2140. 